\title{
O ESPÍRITO DO IMPÉRIO: AS GRANDES CERTEZAS DO ESTADO NOVO EM CHAIMITE
}

\author{
Patrícia Vieira \\ Georgetown University
}

\section{O Espírito e a Matéria no Estado Novo}

O edifício ideológico do Estado Novo português teve como um dos seus alicerces fundamentais a ênfase no espírito. Nas suas intervenções públicas, Salazar menciona frequentemente a crise espiritual da Europa contemporânea, da qual o Portugal republicano teria constituído metonimicamente um exemplo. Assim, num discurso proferido em 1933 intitulado "A Nação na Política Colonial," o chefe do governo declara que "o mundo está sobretudo doente do espírito" (232), sendo que a Europa, como fonte dos valores ocidentais e centro nevrálgico de um leviatão imperial é a principal responsável pela situação de decadência: "Crise europeia, crise do espírito; crise do espírito, crise de civilização" (Salazar, "Portugal perante a Crise" 48). Se a cosmovisão estadonovista encara o alargamento da esfera de influência do comunismo, o eclodir da Segunda Guerra Mundial e o processo de descolonização europeu que se lhe seguiu como sintomas da decadência europeia, Portugal ter-se-ia eximido desta tendência nefasta através da Revolução de 1926. Numa conferência pronunciada em 1942 e posteriormente publicada em forma de livro pela Agência Geral das Colónias, António de Almeida, deputado e professor da Escola Superior Colonial, afirma que "com a Revolução de 28 de Maio de 1926-movimento puramente espiritual, sem um tiro - uma aura de confiante expectativa bafeja e desperta todos os portugueses de lei" (ênfase acrescentada, Política Colonial 20). Saliento nesta declaração a intenção expressa de associar a revolta armada que pôs fím ao demoliberalismo da Primeira República a um desígnio espiritual. O uso de um vocabulário do domínio do inefável-aura, expectativacontribui igualmente para sublinhar a vertente imaterial do movimento. É ainda de notar que a revolução espiritual mencionada pelo autor não é universal mas encontra-se 
limitada aos "portugueses de lei," o que sugere que, apesar dos esforços do governo, nem toda a população teria aderido à espiritualidade preconizada pelo novo regime. Os descrentes no Estado Novo, contaminados pela crise europeia, laboram em equívocos, sendo a tarefa do governo a sua conversão, já que, de acordo com Salazar, um "mundo que se desagrega pela força dos erros ou das armas [...] é preciso refazer "em espírito e em verdade"” ("Problemas Político-Religiosos," 237).

Dada a relevância do espírito nos discursos de definição e legitimação do Estado Novo, torna-se premente proceder à identificação do núcleo semântico deste termo e à delimitação dos seus contornos sócio-políticos. O que entende Salazar por "espírito"? Coincide a noção de espiritualidade delineada pelo chefe de governo e pelos que se lhe encontram próximos com expressões paralelas como a de "política do espírito" proposta por António Ferro? Existe unidade na noção estadonovista de "espírito" ou encontramos variações nas várias etapas da vida do regime e na sua aplicação a diferentes contextos geográficos? Procurarei neste artigo associar a ideia salazarista de espiritualidade à propaganda do regime, levada a cabo sob a designação de "Política do Espírito," concentrando-me na época que vai dos anos trinta à primeira metade da década de cinquenta. Este esforço propagandístico estendeu-se às colónias, sob a forma de apologia do projecto imperial português, para o qual se mobiliza uma versão ligeiramente modificada do "espírito" que se havia já instrumentalizado para defender o Estado Novo na metrópole. Terminarei com uma análise do filme Chaimite: A Queda do Império Vátua (1953), o qual constitui uma súmula dos discursos relativos ao espírito na sua vertente colonial.

\footnotetext{
${ }^{1}$ Luís Reis Torgal considera que a propaganda do Estado Novo utiliza um modelo religioso, já que se apresenta como instrumento de conversão dos descrentes do salazarismo. O cinema constituiu um dos veículos deste esforço propagandístico, destacando-se neste contexto os filmes Revolução de Maio (1937) e Feitiço do Império (1940), ambos realizados por António Lopes Ribeiro e produzidos por organismos do regime.
} 


\section{Chaimite}

A versão salazarista de espiritualidade nasce, contraintuitivamente, a partir de um confronto com o espírito da época:

A Europa tinha experimentado a maior crise mental dos últimos séculos. [...] O filosofismo começara abalando nas inteligências a adesão às verdades eternas e corroendo nos espíritos as grandes certezas. [...] Negou-se Deus, a certeza, a verdade, a justiça, a moral, em nome do materialismo, do cepticismo, do pragmatismo, do epicurismo, de mil sistemas confusos, em que o vácuo foi preenchido com dificuldades" (Salazar, "A Escola" 306-7).

Salazar alia-se aqui a pensadores como Paul Valéry ou Edmund Husserl ao identificar a crise moral e espiritual que assola uma Europa dominada pelo materialismo na sequência da Primeira Guerra Mundial. Contudo, o político português considera que as reflexões filosóficas sobre esta crise que caracterizam o pensamento europeu no início do século vinte põem em causa uma visão unívoca do mundo e revelam a precariedade de um conjunto de valores ocidentais que até então eram tidos como universais. Salazar nega que tais valores possam ser considerados relativos e considera que os detractores das "grandes certezas" são vítimas de sistemas confusos. Na esteira de uma tradição com raízes na escolástica medieval, o salazarismo esboça uma versão da sociedade em que determinadas premissas não estão sujeitas a discussão na medida em que são consideradas verdades imutáveis. Deus surge simultaneamente como uma destas certezas eternas, tais como a moral ou a justiça, e como o garante do sistema. Verifica-se aqui que, seguindo a tradição cristã, Salazar opõe o espírito à matéria, da mesma forma que a eternidade da alma contrasta com as vicissitudes e contingências de um corpo efémero. ${ }^{2}$ No contexto desta

\footnotetext{
${ }^{2}$ Como afirma Salazar numa entrevista com António Ferro: "A verdadeira liberdade [...] só pode existir no espírito dos homens" (Entrevistas 160). Salazar indica aqui que a vertente material da vida dos portugueses se encontra sob a tutela do Estado e deve ser administrada pelo regime, sendo que a liberdade se limita ao domínio espiritual. O Estado, na pessoa de Salazar, ocupar-se-á assim das árduas tarefas relacionas com a matéria, de forma a liberar os portugueses para que estes se dediquem apenas ao espírito.
} 


\section{Patrícia Vieira}

estrutura conceptual, o espírito é associado às grandes certezas em que se fundamenta o Estado Novo, coincidindo assim com as determinantes ideológicas e as opções políticas do regime.

O contraste entre espírito e matéria será igualmente a pedra de toque da política do espírito proposta por António Ferro para dar "alegria" à obra do Estado Novo (Ferro, "Na Fronteira" 55): ${ }^{3}$

Política do Espírito [...] é a que se opõe, fundamental e estruturalmente, à política da matéria. [...] é estabelecer e organizar o combate contra tudo o que suja o espírito [...] tudo o que é feio, grosseiro, bestial, tudo o que é maléfico, doentio, por simples volúpia ou satanismo.

Política do Espírito é aquela que proclama, precisamente, a independência do Espírito, que o liberta da escravidão do materialismo tirânico, insinuante, que pretende constantemente suborná-lo, embriagá-lo. [...]

Aquilo a que se chama espírito do Mal é satanismo, é materialismo. O Espírito do Bem é propriamente o Espírito. (Ferro, Política do Espírito e os Prémios 6-7)

O conceito de "matéria" esboçado por Ferro engloba tudo o que põe em causa a sociedade ordenada segundo as directrizes do regime: "O que atacamos e atacaremos, cada vez mais, é a inquietação da desordem [...]" (Política do Espírito e os Prémios 11). ${ }^{4}$ A oposição ao Estado Novo ganha contornos diabólicos na formulação de Ferro, que recorre mais uma vez a uma terminologia religiosa ao

\footnotetext{
${ }^{3}$ Para uma análise detalhada da Política do Espírito de António Ferro ver Os Anos de Ferro de Jorge Ramos do Ó.

${ }^{4}$ De acordo com Ferro, a inquietação característica da arte só tem lugar na medida em que caminhe para o equilíbrio: "A resposta fácil, aparentemente fácil, a esta defesa do Espírito, é a apologia da inquietação humana como única fonte possível da literatura e da arte. [...] Mas há inquietação e inquietação, isto é, aquela que procura instintivamente a ordem e a que se compraz na desordem, a inquietação construtiva e a inquietação diabólica, nihilista. [...] Defendo e proclamo, acima de tudo, aquela saudável inquietação que marcha, sem desvios, através de acidentais desequilíbrios, para o Equilíbrio, a inquietação da Ordem [...]. O que atacamos e atacaremos, cada vez mais, é a inquietação da desordem [...]" (A Política do Espírito e os Prémios 8-11). A arte apenas goza de liberdade dentro das apertadas balizas estabelecidas pelo Estado.
} 


\section{Chaimite}

caracterizar de satânico o materialismo, palavra que nos seus discursos, bem como nos de Salazar, surge tingida de colorações comunistas. O triunfo do espírito coincide assim com a libertação do materialismo ou, noutras palavras, com a adesão aos valores do Estado Novo. Numa perversão da filosofia kantiana, Ferro equipara a versão estadonovista do espírito à lei moral de Kant, na medida em que qualquer ser racional deveria encontrar os valores espirituais do regime em si mesmo e reconhecê-los como seus, sendo que os indivíduos são tanto mais livres quando mais se submetem a estas normas.

Não obstante o quiasmo que separa espírito e matéria, a Política do Espírito proposta por António Ferro não deixa de ter consequências concretas. $\mathrm{O}$ próprio Ferro, num artigo que publica no Diário de Notícias em 1932 onde expõe uma versão embrionária da actividade que irá desenvolver ao serviço do Estado Novo, salienta a materialidade do espírito:

Mas que se faça uma Política do Espírito, inteligente e constante, consolidando a descoberta, dando-lhe altura, significado e eternidade. Que não se olhe o espírito como uma fantasia, como uma ideia vaga, imponderável, mas como uma ideia definida, concreta, como uma presença necessária, como uma arma indispensável para o nosso ressurgimento. O Espírito, afinal, também é matéria, uma preciosa matéria, a matéria-prima da alma dos homens e da alma dos povos... (Entrevistas 229)

${ }^{5}$ Ferro reitera a noção de que o espírito é indispensável ao progresso material das nações em várias passagens do texto: "O desenvolvimento premeditado, consciente, da Arte e da Literatura é tão necessário, afinal, ao progresso duma nação como o desenvolvimento das suas ciências, das suas obras públicas, da sua indústria, do seu comércio e da sua agricultura. [...] A Política do Espírito [...] não é apenas necessária, se bem que indispensável em tal aspecto, ao prestígio exterior da nação. Ela é também necessária ao seu prestígio interior, à sua razão de existir. Um povo que não vê, que não lê, que não ouve, que não vibra, que não sai da sua vida material, do Deve e Haver, torna-se um povo inútil e mal-humorado. A Beleza-desde a Beleza moral à Beleza plástica-deve constituir a aspiração suprema dos homens e das raças. A literatura e a arte são os dois grandes órgãos dessa aspiração, dois órgãos que precisam duma afinação constante, que contém, nos seus tubos, a essência e a finalidade da Criação" (Entrevistas 226-7). 


\section{Patrícia Vieira}

Esta passagem sublinha que espírito se reflecte na vida material dos povos. A Política do Espírito traçada por Ferro traduzir-se-á, concretamente, nas acções do Secretariado de Propaganda Nacional (SPN), instituído por Salazar em 1933 e metamorfoseado em 1944, numa alteração cosmética resultante das novas circunstâncias políticas associadas ao final da Segunda Guerra Mundial, em Secretariado Nacional de Informação, Cultura Popular e Turismo (SNI). Este organismo, dirigido por Ferro desde a sua criação até $1949,{ }^{6}$ procurará garantir a adesão dos portugueses e mesmo da comunidade internacional à noção de espiritualidade proposta pelo Estado Novo. ${ }^{7}$ A propaganda terá como objectivo mostrar ao país e ao estrangeiro a evidência das "grandes certezas," " e pôr a descoberto as calúnias e mentiras dos críticos do regime (Salazar, "Propaganda Nacional" 264). Visto que, em política, "só existe o que o público sabe que

\footnotetext{
${ }^{6}$ Desconhece-se ao certo o motivo pelo qual Ferro foi afastado do SNI. Fernando Guedes afirma que a versão familiar sobre a sua substituição alude a motivos de saúde. Contudo, o autor questiona esta explicação e declara que a razão teria sido provavelmente a mudança na situação política internacional após a derrota do fascismo na Segunda Guerra Mundial (32). Heloísa Paulo declara que a saída de Ferro do SNI é frequentemente interpretada como um sinal do afastamento da instituição em relação aos valores do regime (98). Num discurso de 1948 proferido no acto inaugural da exposição "14 Anos de Política do Espírito," o próprio Ferro enumera algumas das razões pelas quais a actividade do SPN/SNI não teve maior amplitude, entre as quais se contam a desconfiança e incompreensão com que foram recebidos alguns dos seus projectos (Política do Espírito Apontamentos 18-20).

${ }^{7}$ Heloísa Paulo afirma que a acção do SPN/SNI se divide numa vertente interna e noutra externa. O objectivo desta última é promover uma imagem positiva do Estado Novo junto da comunidade internacional, bem como, especialmente a partir de meados dos anos 40, desenvolver o turismo estrangeiro em Portugal (74-5).

${ }^{8}$ Salazar acredita que as verdades nas quais se baseia o regime são evidentes e a propaganda torna-se apenas necessária para dissipar a ignorância. O SPN/SNI não seria deste modo um organismo criado para elogiar o governo mas sim para apresentar factos: "o Secretariado denomina-se da propaganda nacional. Quem penetrar bem o seu significado, entenderá que não se trata duma repartição de elogio governativo [...]; compreenderá que o Secretariado não é um instrumento do Governo mas um instrumento de governo no mais alto significado que a expressão pode ter" (258).
} 


\section{Chaimite}

existe" (Salazar, "Propaganda Nacional" 259), cabe ao secretariado informar e educar politicamente os cidadãos de forma a que estes contemplem as verdades espirituais em que se baseia o governo da nação e regulem a sua existência concreta de acordo com estes dogmas (Salazar, "Fins e Necessidades da Propaganda" 196-9; 210).

A actuação do SPN/SNI, bem como o aparato de censura estabelecido pelo governo, definem o panorama artístico do Estado Novo. ${ }^{9}$ O SPN/SNI estabelece um regime de incentivos à cultura, restringindo contudo o seu apoio a manifestações artísticas que subscrevam o ideário espiritual do regime. Como afirma Ferro a respeito dos prémios literários atribuídos pelo secretariado:

Criando-se [os prémios literários], não quisemos estimular, como é fácil agora deduzir, o satanismo literário, a política da matéria, mas a política do espírito [...]. Temos outros objectivos [...] mas esses objectivos são corajosa e francamente limitados por certas balizas morais e espirituais. [...] Quem não concordar com tais princípios - e com toda a acção que deles deriva - só tem um caminho a seguir: não concorrer aos nossos prémios (Política do Espírito e os Prémios 18-9).

Espartilhada pelo olhar omnipresente da censura e pelas contingências de financiamento, muita da arte estadonovista acaba por espelhar os valores do salazarismo. Esta situação de dependência afecta particularmente o cinema. Por um lado, o fácil acesso do público, mesmo da camada iletrada da população, ao cinema nacional, implicava que os filmes fossem sujeitos a uma apertada censura. ${ }^{10}$ Por outro lado,

\footnotetext{
${ }^{9}$ Logo em 1926, após a revolta militar, são promulgados dois decretos que limitam a liberdade de imprensa. Em 1933 são criadas as Comissões de Censura e o visto censor prévio que policiam publicações ou emissões e eliminam quaisquer elementos que não se coadunem com a ideologia do regime (Paulo 30). A limitação da liberdade de expressão é comum aos vários regimes totalitários europeus da primeira metade do século vinte. $\mathrm{O}$ franquismo espanhol, por exemplo, desenvolveu igualmente uma intricada rede de censura e propaganda, tendo em vista manipular a opinião pública no país (ver Sevillano Calero).

${ }^{10}$ António Ferro reconhece a relevância do cinema como forma de chegar a um público alargado: "O Cinema constitui, minhas senhoras e meus senhores, um desses problemas fundamentais, vitais, cuja importância,
} 


\section{Patrícia Vieira}

dadas as características de produção da arte cinematográfica, que requer um elevado investimento de capital, os realizadores viam-se frequentemente forçados a recorrer a subvenções do Estado, o que significava que os seus filme se tinham que enquadrar nas directrizes enunciadas pelas autoridades. ${ }^{11}$

Em Fevereiro de 1948 é promulgada a lei n. 2027 de protecção ao cinema nacional que, entre outras disposições, cria o Fundo de Cinema Nacional, administrado pelo SNI, cujo objectivo, era, de acordo com o seu Artigo $1^{\circ}$, "proteger, coordenar e estimular a produção do cinema nacional $[. .$.$] tendo em atenção a sua função social e educa-$ tiva, assim como os seus aspectos artístico e cultural." É significativo que, na lei, a menção da vertente social e educativa do cinema ou, por outras palavras, a sua instrumentalização enquanto veículo de propaganda dos ideais do espírito defendidos pelo regime, precede a referência a aspectos artísticos. Com efeito, no discurso em que apresenta esta lei, António Ferro estabelece uma categorização dos vários filmes produzidos no país e assinala à partida quais os géneros que receberão mais prontamente auxílio do fundo, nomeadamente, filmes históricos, documentários, filmes de natureza poética e filmes do quotidiano ("O Estado e o Cinema" 67-9). ${ }^{12}$ Ferro acentua, mais uma vez, que as obras

infelizmente, nem sempre é reconhecida. A sua magia, o seu poder de sedução, a sua força de penetração são incalculáveis" ("Grandeza e Miséria do Cinema Português" 44). Devido a esta força de penetração, o cinema foi sujeito a uma apertada censura no Estado Novo e muitas obras sofreram cortes consideráveis (ver António). Alves Costa menciona o caso do filme Vidas sem Rumo (1956) de Manuel Guimarães, cuja exibição se tornou impossível após extensos cortes da censura (109). Para além dos cortes de cenas, a lei 2027 de 1948 instituiu uma outra forma de censura indirecta. Esta lei determina que todos os filmes estrangeiros sejam legendados e não falados, restringindo-se assim o seu visionamento ao público letrado e tornando-os inacessíveis para uma larga camada da população ("Leitura Obrigatória").

${ }^{11} \mathrm{O}$ Estado português não produziu directamente muitas longas-metragens de ficção, concentrando-se a propaganda em documentários. Contudo, o regime concedeu apoio financeiro a privados para a realização de filmes de ficção, desde que estes se enquadrassem na ideologia salazarista (Torgal 72).

${ }^{12}$ Ferro aponta como exemplo de filmes de natureza poética a obra AnikiBobó de Manuel de Oliveira ("Estado e o Cinema" 65). Os filmes do 


\section{Chaimite}

financiadas serão as que exprimem os valores estadonovistas: "É natural que este critério nos leve a proteger em princípio e por princípio, certos produtores e realizadores que se adaptem com mais compreensão ao nosso critério" ("O Estado e o Cinema" 70). Estas restrições levaram a que o cinema português se tornasse, com raras excepções, um veículo da ideologia do regime, tanto no que diz respeito aos valores espirituais que deveriam reger a metrópole como às políticas propostas para o império. ${ }^{13}$

\section{O Espírito do Projecto Imperial}

A construção retórica da ideologia do Estado Novo confere uma posição de destaque às colónias ultramarinas, que são entendidas como uma instanciação do espírito português. Como afirma em 1933 o então Ministro das Colónias Amindo Monteiro: "O dado essencial da colonização é de ordem humana - isto é, de natureza espiritual" ("Directrizes duma Política" 29). A mesma convicção é reiterada numa publicação conjunta do SPN e da Agência Geral das Colónias, na qual se afirma: "o Estado Novo [...] pôs com a máxima continuidade, como se de um prévio plano a cumprir se tratasse, a política moral e a política do espírito que haviam de conduzir e conduziram a uma consciência firme da obra do Império" (Obra Colonial do Estado Novo 73). Em 1942, António de Almeida, mencionado acima, associa igualmente a expansão marítima portuguesa no período da Renascença a "manifestações do espírito" que incluem o "desenvolvimento da ciência e da cultura," o "aperfeiçoamento da língua" e o "incremento das artes" (Política Colonial 5).

Apesar dos esforços para realçar os elementos incorpóreos da colonização ultramarina, é inegável que os valores espirituais se encontram neste caso associados a interesses

quotidiano são "histórias contadas naturalmente, como se escreve bem ou se pinta bem, sem a preocupação dos grandes momentos, mas feitos pelo contrário, com os nadas de todos os dias" ("Estado e o Cinema" 66).

${ }^{13}$ Como afirma Luís Reis Torgal: "A ideologia indirecta ou contextualno que respeita à temática $[\ldots]$, ao ambiente [...], à moral social [...]está de resto bem presente no cinema português, nomeadamente nos anos trinta e quarenta e mesmo até na década de cinquenta" (71). 
materiais. No discurso "O Império Colonial na Economia da Nação" de 1936 Salazar reconhece que as colónias são essenciais à economia do país como fornecedoras de matérias-primas e mercado para onde exportar a produção industrial, bem como na sua qualidade de destino de emigração para o excedente populacional que a metrópole não logra absorver (158-9). Contudo, a vertente material da colonização é invariavelmente subordinada ao espírito, sendo que a prosperidade económica é apresentada como dependente da moralidade: "Crescemos tanto em potência material [...] como em força espiritual” (Almeida, Política Colonial 8). As verdades do espírito constituem uma condição sine qua non da acção dos portugueses, que relegarão sempre para segundo plano os interesses materiais: "Se, por exemplo, nos sentimos indissoluvelmente presos ao Estado português na Índia, não é pelos interesses materiais [...] mas porque constitui, com Macau, um padrão do espírito do Ocidente que tivemos a glória, cometemos a audácia, dizemos o sacrifício de implantar ali" (Salazar, "A Nação Portuguesa Irmandade" 284). Num caso de tensão entre princípios espirituais e materiais, os primeiros prevalecerão sempre em detrimento dos segundos, que se lhe encontram sujeitos.

A superioridade espiritual portuguesa e o concomitante desenvolvimento material da nação são apresentados como apanágio de governos fortes: "Enquanto fomos espiritual e materialmente superiores e enquanto nos guiaram governos autoritários e tivemos em vista apenas dilatar a Fé e o Império, a chefia do país era idónea e a sua vontade reflectia-se beneficamente em todos os departamentos da vida nacional" (Almeida, Política Colonial 7). A política ultramarina estadonovista tece deste modo um discurso de auto-justificação ao pressupor uma teleologia do espírito, que se concretiza em progresso material nas colónias, numa ascensão espiral cuja força motora é o autoritarismo. O regime apropria-se assim no seu ideário da noção hegeliana de Espírito (Geist) que encarna no mundo gerando a evolução histórica. ${ }^{14} \mathrm{O}$

${ }^{14}$ De acordo com Hegel, o espírito opõe-se à matéria: "The opposite of Spirit is Matter. The essence of matter is gravity; the essence of Spirit is 


\section{Chaimite}

Espírito, identificado com Deus como princípio máximo de racionalidade, manifesta-se segundo Hegel nos vários momentos que compõem a história humana. A actividade dos homens e a sucessão de tempos históricos constituem uma forma do Espírito, abstracto e fechado em si mesmo, se tornar concreto e ganhar consciência de si mesmo e da sua liberdade. O Espírito, que existia no início só em potência, realiza-se deste modo no devir histórico através de um processo dialéctico do qual os homens e as nações são instrumentos para culminar, segundo Hegel, na sua completa materialização, que coincidirá com a plena espiritualização do mundo no fim da história da humanidade. A hybris salazariana, apoiada num milenarismo de contornos sebastianistas, consiste em sugerir que o povo português superou a decadência europeia ao transformar-se na encarnação última - no telos - do Espírito ou, de uma forma mais radical, que Estado Novo é o Espírito, agora domesticado numa adaptação ao "caso comezinho" português, que se traduz na tríade Deus, Pátria e Família, sendo que "Pátria" engloba tanto a metrópole como as colónias.

A primazia do espírito na concretização do projecto colonial português encontra-se associada a duas outras noções interdependentes: civilização e cristianismo. O Acto Colonial que, elaborado por Salazar e promulgado em 1930, irá constituir a base legal da colonização portuguesa durante as primeiras décadas do Estado Novo, começa por afirmar, logo no Artigo 20: "É da essência orgânica da Nação Portuguesa, desempenhar a função histórica de possuir e colonizar domínios ultramarinos e de civilizar as populações indígenas que neles se compreendam, exercendo também a influência moral que lhe é adstrita pelo Padroado do Oriente" (Obra Colonial 83). ${ }^{15}$ Segundo este documento, o domínio de

freedom" (22). Mas o espírito necessita da matéria para passar de um estado potencial a um concreto e, desta forma, tornar-se auto-consciente.

15 A civilização das populações colonizadas e a sua elevação espiritual encontram-se assim associadas à evangelização veiculada pelos portugueses: "consideramo-nos felizes por nos ser possível elevar espiritualmente os domínios e reforçar com novas condições de trabalho missionário a unidade moral de Portugal de Aquém e de Além-Mar" (ênfase acrescentada; Salazar, "Problemas Político-Religiosos" 241). 
possessões ultramarinas faz parte da essência de Portugal como nação, sendo que o direito de governar aqueles territórios é justificado por uma acção civilizadora de teor religioso. ${ }^{16}$ Portugal teria assim procedido à conquista e colonização de vastas áreas fora da Europa com o intuito de trazer os benefícios da civilização ocidental e da evangelização a outros povos: "devemos organizar cada vez mais e mais eficazmente e melhor a protecção das raças inferiores cujo chamamento à nossa civilização cristã é uma das concepções mais arrojadas e das mais altas obras da colonização portuguesa" (Salazar, "Nação na Política Colonial" 237). Esta noção é reiterada num discurso proferido por ocasião da assinatura da Concordata com a Santa Sé e do Acordo Missionário em 1940, no qual Salazar proclama o papel constitutivo da doutrina cristã nas normas morais que presidem ao Estado e afirma que a humanidade com que os colonizadores portugueses teriam tratado os povos colonizados deriva da sua vocação religiosa ("Problemas PolíticoReligiosos" 233, 237). ${ }^{17}$

Um dos objectivos do SPN/SNI era dar a conhecer a espiritualidade do projecto colonial português, nas suas vertentes civilizadora e evangelizadora, dentro e fora de Portugal. A secção externa desta instituição tinha assim como função, "elucidar a opinião internacional sobre a nossa acção civilizadora e, de modo especial, sobre a acção exercida nas colónias e o progresso do Império Ultramarino"

\footnotetext{
${ }^{16}$ A fé nos dirigentes políticos complementa a fé religiosa, sendo que a conjugação de ambas é indispensável à manutenção do Império: "O que é necessário, fundamentalmente, à constituição de um Império? Um pensamento criador e uma fé inquebrantável nos dirigentes pelo espírito" ("A Obra Colonial" 24). Esta afirmação implica que as acções do regime poderão parecer tão insondáveis como os desígnios de Deus mas, tal como os mandamentos divinos, as leis do estado deverão ser obedecidas sem questionamentos.

${ }^{17}$ Neste discurso Salazar menciona, mais uma vez, a correlação entre a vertente material e espiritual do poder: "De que se trata? Simplesmente de completar a obra política do Acto Colonial com a sanção da posse espiritual conferida pela Santa Sé, e com a nacionalização da obra missionária que se integra definitivamente na acção colonizadora portuguesa" ("Problemas Político-Religiosos" 240). A posse espiritual das colónias complementa assim o domínio político destes territórios.
} 


\section{Chaimite}

(artigo 5 do decreto-lei 23054, citado em Paulo, 75). Este propósito torna-se mais urgente a partir de finais dos anos quarenta, quando a maioria dos países europeus passa por um processo de descolonização que conduzirá à independência da grande maioria dos seus territórios ultramarinos. Face a uma crescente pressão internacional no sentido de conferir autonomia às colónias, denominadas a partir de 1951 de "Províncias Ultramarinas,"18 o Estado Novo procurará acentuar a imagem de Portugal como país pluricontinental, noção que se encontrava já presente na concepção do regime desde a sua fundação. O cinema fará parte do esforço do governo para promover a aceitação do estatuto de Portugal como país colonizador. Este empenho traduzir-se-á na produção de vários documentários, bem como no apoio a longas-metragens como Feitiço do Império (1940) de António Lopes Ribeiro e Chaimite: A Queda do Império Vátua (1953), realizado por Jorge Brum do Canto. ${ }^{19}$ Em Chaimite digladiam-se a faceta espiritual e material, guerreira e bucólica da colonização portuguesa em África. O restante deste artigo será dedicado a uma análise da obra de Brum do Canto sob o prisma das coordenadas da "Política do Espírito" traçadas pelo estadonovismo como guia para a produção artística em Portugal.

\section{A Política do Espírito em Chaimite}

De acordo com Salazar, os artistas são responsáveis pelas obras que criam, que devem ser colocadas ao serviço da sociedade ("Para Servir de Prefácio" xxiii). ${ }^{20}$ Desta forma,

18 No intuito de sublinhar que os territórios ultramarinos são parte integrante de Portugal, o Estado Novo cria a divisão administrativa de "província ultramarina." A primeira região a receber esta designação foi o Estado Português da Índia, em 1946, seguindo-se todas as restantes colónias em 1951. O conceito de "Império Colonial" é assim teoricamente abolido e substituído pelo de "Ultramar."

${ }^{19}$ Feitiço do Império narra uma viagem do luso-descendente Luís (Luís de Campos), que habita em Bóston, pelas colónias portuguesas em África. O jovem, que se prepara no início do filme para se naturalizar e casar com uma americana, viaja a África a conselho pelo pai e acaba por ficar fascinado com o império português.

${ }^{20}$ Salazar considera que o amoralismo da arte pela arte é nocivo para a sociedade e deve ser desencorajado ("Para Servir de Prefácio" xxi-ii). 
um filme como Chaimite, cujo enredo se concentra na guerra entre os portugueses e o império vátua em Moçambique em finais do século dezanove, terá como obrigação salientar a relevância dos factos históricos que representa no contexto social em que é produzido. Tendo em vista a posição de realce conferida ao Império no Estado Novo, cabe a qualquer filme sobre o tema sublinhar os ideais colonizadores do regime e transmiti-los aos cidadãos, de forma a atingir o que Ministro das Colónias Amindo Monteiro denominou logo em 1933 de "imperialização da vida portuguesa":

Como ideal de que a própria unidade não deve ser senão um instrumento, assim nos iremos aproximando daquilo a que eu ousarei chamar a imperialização da vida portuguesa-quero dizer, a compreensão de que Portugal, sendo uma potência mundial, tem de dirigir-se em todos os momentos, de governarse com o sentimento e a responsabilidade que esse facto importa ("Directrizes duma Política Ultramarina" 15).

Esta imperialização do país corresponde a uma interiorização do seu papel de colonizador, uma posição que, sendo naturalizada, passaria a informar todas as actividades da sociedade portuguesa nos domínios interno e externo. Contribui Chaimite para este desiderato de imperialização de Portugal? Conduz o filme à elevação moral dos portugueses, inserindo-se assim dentro das normas traçadas pela "Política do Espírito"?

No seu estudo exaustivo sobre Chaimite, a história da sua exibição e a recepção da obra na comunicação social da época, Jorge Seabra fornece vários dados que permitem situar o filme em relação ao discurso oficial sobre o Ultramar e determinar o seu estatuto vis-à-vis a propaganda do regime. Seabra menciona que, numa entrevista com Jorge Brum do Canto, o realizador afirmou não ter tido nunca qualquer tipo de envolvimento institucional e político com o salazarismo (Seabra 236). Acresce que algumas cenas inicialmente projectadas para o filme foram excluídas do guião técnico pela

António Ferro partilha desta opinião e cita as palavras de Crommelynck: "A arte pela arte só pode gerar monstros" (Política do Espírito e os Prémios 12). 


\section{Chaimite}

censura e não foram assim filmadas (Seabra, 245). ${ }^{21}$ Contudo, apesar de Chaimite não poder ser denominado, stricto sensu, um filme de propaganda, até porque a sua produção não foi da responsabilidade de um organismo do Estado mas sim de uma companhia privada, nomeadamente a Cinal, Cinematografia Nacional, a visão do Império transmitida pelo filme não deixa de seguir de perto a ideologia colonial difundida pelo Estado Novo, que Brum do Canto, aliás, partilhava. ${ }^{22}$ Esta proximidade resulta no auxílio do regime ao projecto e na apreciação oficial positiva da obra aquando da sua estreia.

Numa entrevista concedida ao jornal Notícias em 1950, Brum do Canto afirma que conta com o assentimento do Presidente do Conselho e da Agência Geral das Colónias para a realização do filme, apoio que se irá concretizar na ajuda financeira concedida à iniciativa pelo Fundo Nacional de Cinema (Seabra 255). ${ }^{23}$ A estreia a 4 de Abril de 1953 no Monumental contou com a presença de várias entidades oficiais, incluindo alguns ministros, e a obra foi extremamente bem recebida pela imprensa da época, que destaca as suas qualidades como instrumento de unificação dos territórios ultramarinos sob a soberania portuguesa e como veículo para a difusão da missão civilizadora de Portugal em África (Seabra 255-60). A divulgação de Chaimite foi ainda realizada através de uma nota informativa do SNI, reproduzida em vários periódicos, onde se louvava a grandeza do tema abor-

${ }^{21}$ A censura excluiu do guião uma cena na qual Daniel (Artur Semedo) violentava Maria. A outra cena excluída, que comentarei abaixo, narrava a forma como Paiva Couceiro (Brum do Canto) espancava três jornalistas estrangeiros por caluniarem Portugal (Seabra 245-6).

${ }^{22}$ Brum do Canto parece glorificar as campanhas africanas de finais do século dezanove: "Macontene, Chaimite, Manjacaze, Magul, Coolela, nomes amassados de terra e sangue, ao clarão das lanças a luzir e de palhotas a arder, por entre o nevoeiro da pólvora, nomes bárbaros, de sabor simultaneamente ácido e adocicado, para todo o sempre gravados em nossa alma agradecida [...]" (citado em Seabra, 240). O nacionalismo de Brum do Canto e a sua visão do Império Colonial levam Jorge Seabra a apelidar o realizador de "homem do "espírito," numa alusão à "Política do Espírito" de António Ferro (271).

${ }^{23} \mathrm{O}$ Ministério do Exército concedeu também o seu apoio à realização do filme, que é dedicado "ao exército português." 
dado e se considerava ser a película de visionamento obrigatório para todos os portugueses (Seabra 257-8). A distribuição comercial do filme aconteceu um pouco por todo o país e mesmo nas colónias (Seabra 264-70), o que aponta tanto para o interesse das autoridades na sua difusão como para a atracção que os eventos da narrativa exerceram sobre o público. O filme foi distinguido em 1954 com o Grande Prémio do SNI e um dos protagonistas da narrativa, Emílio Correia, foi galardoado com o Prémio para o Melhor Actor. Após o ano de estreia, Chaimite continuou a ser apresentado em iniciativas militares e culturais do Estado Novo, que incluíram a comemoração de datas oficiais como a subida ao poder de Salazar, o Dia da Revolução Nacional ou o Dia de Portugal (Seabra 273). Verifica-se que, como afirma Seabra, "não estamos perante um 'filme de regime' [...] mas sobretudo um 'filme do regime,' que, apesar de não provir da iniciativa oficial, pelo tema abordado e pelos objectivos que os autores se propunham concretizar, não deixava de interessar ao Estado Novo" (Seabra 271). A obra de Brum do Canto irá assim apresentar uma imagem da colonização portuguesa impregnada dos valores do espírito que, de acordo com a ideologia estadonovista, nortearam a presença dos portugueses no Ultramar.

As primeiras cenas de Chaimite permitem identificar as linhas de força que definem a obra. O filme abre com uma imagem que mostra em grande plano uma colecção de espingardas e escudos de guerra, apresentando em seguida um grupo de africanos numa roda a mover-se ao som de cantos guerreiros. Estes momentos iniciais apontam desde logo para a beligerância da população negra que contrasta com a disposição pacífica dos portugueses, representados nesta sequência pela Tia Rosa e pela sua sobrinha Maria. Estas encontram-se a cultivar a terra quando são avisadas por António (Emílio Correia) de que está em curso uma rebelião e aconselhadas a refugiarem-se em Lourenço Marques. A crueldade da população nativa é ainda enfatizada através da representação do assassínio de uma mulher e de uma criança por vários africanos que correm desordenadamente atrás dos colonos portugueses enquanto estes fogem da insurreição. 


\section{Chaimite}

Nos minutos iniciais estabelece-se assim uma oposição entre as inclinações belicosas e tumultuosas dos insurrectos e a sociedade laboriosa e ordenada implantada por Portugal em África. Salienta-se no filme a forma como os colonos se encontram adaptados à vida em Moçambique, cultivando a terra e desenvolvendo o comércio, uma ideia que se coaduna com o discurso oficial do regime. Com efeito, Salazar proclama a maleabilidade dos portugueses, que se adaptariam sem grandes dificuldades ao clima e à cultura nativa das regiões que colonizam: "Les Portugais doivent probablement leur renommée d'excellents colonisateurs à leur rare faculté d'adaptation. Ils ont en effet une grande facilité à s'acclimater sous les cieux les plus inhospitaliers, et ils comprennent très vite la mentalité, la vie, les coutumes et les acivités des peuples qui leur sont étrangers" (Garnier 153) ${ }^{24}$ O chefe do governo adopta assim a tese do sociólogo brasileiro Gilberto Freyre, segundo o qual a propensão lusa para interagir com outros povos teria resultado numa fusão de culturas nas várias regiões do mundo onde os portugueses se fixaram. ${ }^{25}$

A vocação portuguesa para a colonização está associada à ideia de que o colonialismo luso teria tido um carácter mais benévolo do que as outras formas europeias de domínio colonial. Salazar afirma assim a Christine Garnier: "Chacun sait que la domination portugaise s'est toujours exercée avec douceur, dans le respect des hommes et de leurs coutumes. Nous n'avons jamais eu de préjugés de race. D'un mot, on

\footnotetext{
${ }^{24}$ No discurso "Aos Portugueses da América do Norte" Salazar louva igualmente o "formidável poder de adaptação [dos portugueses] às mais variadas condições locais de vida e de trabalho" (168).

${ }^{25}$ Gilberto Freyre afirma que o colonialismo português teria tido um carácter mais benévolo do que outras formas de colonização. Freyre não nega, por exemplo, a crueldade da escravatura, mas afirma que se estabeleceram algumas relações próximas entre amos e escravos, que tornaram a instituição menos inumana. $\mathrm{O}$ autor desenvolve a teoria do lusotropicalismo, segundo a qual as características do povo português lhe permitiram adapatar-se com facilidade a regiões tropicais e contribuiram para a miscigenação que teve lugar nas colónias lusófonas. Salazar afirma ainda, neste sentido, numa entrevista a Christine Garnier: "Il [le portugais] crée, enfin, par des fusions de races, d'autres types de populations locales mieux adaptées aux conditions du climat" (154).
} 


\section{Patrícia Vieira}

ne trouvera $[\ldots]$ de quelques violences exercées ni même d'une civilisation imposée" (152). ${ }^{26}$ Embora reconheça aqui que a ocupação de territórios africanos pelos portugueses é uma forma de dominação, Salazar salienta que este processo ocorreu sem violência ou preconceitos raciais e deixa implícita a noção de que esta ocupação foi vantajosa para os africanos, que puderam assim elevar-se espiritualmente ao contactar com a civilização europeia. ${ }^{27}$

As personagens portuguesas representadas em Chaimite subscrevem a visão estadonovista do projecto colonial como uma forma de civilizar e trazer o progresso ao continente africano. Contudo, a ausência de descriminação proclamada por Salazar é desmentida pelas próprias opções estéticas e narrativas da obra. Como afirmam Robert Stam e Louise Spence no seu estudo sobre colonialismo e racismo no cinema, a indústria cinematográfica tem, ao longo da sua história, recorrido a várias técnicas para exprimir a inferioridade dos povos colonizados, tais como o favorecimento da identificação do espectador com a perspectiva do colonizador através do ponto de vista criado pelo posicionamento da câmara, a negação da subjectividade do colonizado, ou a criação de uma imagem negativa dos povos não-ocidentais. Várias destas técnicas que têm como função deslegitimar a revolta dos colonizados contra o domínio europeu e enfatizar a sua menoridade são utilizadas em Chaimite. Ao contrário do que acontece com os colonos, à maioria dos africanos que surgem no filme não é atribuído um nome, não se desenvolve a sua vida interior no decorrer da acção, e a sua

\footnotetext{
26 Estas palavras de Salazar devem ser entendidas no contexto da conjuntura internacional e da pressão sobre Portugal para conferir independência às suas colónias. Salazar procura transmitir a ideia de que o colonialismo português não é uma imposição e se exerce sem violência. $\mathrm{Na}$ mesma entrevista com Garnier Salazar afirma ainda que a independência das colónias portuguesas se encontra fora de questão: "Vous comprenez ainsi à quel point votre question sur l'émancipation future de nos colonies est en dehors des réalités prévisibles" (158).

${ }^{27}$ Salazar nega a existência de racismo no seio do Império português: "A Índia tem problemas raciais, mas não pode pô-los contra nós, que não os temos dentro dos nossos territórios e por toda a parte nos erguemos contra as discriminações de que os seus próprios filhos são vítimas" ("Questões de Política Interna" 449).
} 


\section{Chaimite}

participação circunscreve-se a uma parte reduzida da narrativa (Seabra 244-5). A população africana surge tipificada na obra em dois grupos distintos: os revoltosos, que são indiscriminadamente apelidados de traidores, incapazes de reconhecer a superioridade moral dos colonizadores, e os que colaboram com os portugueses fornecendo informações sobre a sedição, que são apresentados de forma positiva. ${ }^{28}$ Estas duas categorias correspondem à divisão estabelecida por Amindo Monteiro nas suas "Directrizes duma Política Ultramarina":

Mas uma parte das sociedades negras, por toda a África, permanece imóvel dentro dos moldes da sua velha organização. [...] A sua nudez externa é o espelho da sua nudez moral. [...] dentro de poucas dezenas de anos, da face da terra terão desaparecido as raças negras que não puderam escalar as ásperas sendas da civilização (28).

Os africanos que não aceitam com docilidade o domínio português, recusam a assimilação, e combatem o império reagem desta forma devido à sua "nudez moral," que os impede de contemplar a superioridade espiritual dos portugueses. Chaimite encapsula assim uma contradição na atitude estadonovista face aos habitantes nativos das possessões ultramarinas ao aderir à construção discursiva da situação dos colonizados, cujos costumes e tradições seriam respeitados, discurso este que contrasta com a forma redutora como a população negra é apresentada na tela.

Apesar da sua suposta benevolência e vocação para a paz, os portugueses não deixam se mostrar corajosos quando confrontados com uma situação de guerra face aos que se rebelam contra os ideais do espírito. Os comandantes que figuram em Chaimite-Mouzinho de Albuquerque (Jacinto Ramos), Paiva Couceiro (Jorge Brum do Canto) e Caldas Xavier (Augusto de Figueiredo) — representam militares que realmente combateram nas campanhas africanas em finais do

\footnotetext{
${ }^{28}$ Os africanos que se rebelam contra os portugueses são assim qualificados de traidores, enquanto os africanos que traem outros africanos fornecendo informações aos colonizadores sobre a revolta são considerados corajosos e patriotas.
} 


\section{Patrícia Vieira}

século dezanove, personalidades cuja memória é glorificada no filme. ${ }^{29}$ Estes oficiais são elevados à categoria de heróis que instanciam as virtudes de nobreza e patriotismo características dos colonizadores. Em situações de batalha, os líderes do exército mantêm a calma e encaram o perigo sem hesitações. Esta atitude é replicada pelos soldados, que se organizam em fileira e enfrentam com espingardas e sem pestanejar as hordas de combatentes africanos que acometem desordenadamente o exército português. ${ }^{30}$

O virtuosismo de Brum do Canto como realizador transparece nestas cenas de movimentação de massas, em que figura não só o choque entre dois exército mas a luta entre duas culturas. A primazia tecnológica dos portugueses é posta em evidência ao longo do filme e leva a que os africanos sejam derrotados em batalhas nas quais eram numericamente superiores. Estas vitórias são significativamente interpretadas em Chaimite como milagres que atestam o mandato divino dos colonizadores sobre a população nativa e não como o resultado da posse de melhor armamento e mais avançadas técnicas de combate. O filme sugere assim que a vantagem tecnológica ou material dos portugueses se encontra associada à sua superioridade moral. A serenidade e a coragem com que o exército dos colonizadores defronta os guerreiros nativos devem-se, segundo esta perspectiva, à fé

\footnotetext{
${ }^{29}$ Esta glorificação do exército replica o discurso estadonovista. Salazar descreve da seguinte forma a condição dos soldados: "Para o soldado, porém, não há a aldeia e a região, a província, a colónia-há o território nacional; não há a família, os parentes, os amigos, os vizinhos-há a população que vive e trabalha nesse território: só há, numa palavra, a Pátria, em toda a sua extensão material, no conjunto dos seus sentimentos e tradições, em toda a beleza da sua formação histórica e do seu ideal futuro. [...] E parece que é por esse consumo de vidas que a Pátria se mantém, e aumenta a sua beleza e engrandece o seu poder" ("Elogio das Virtudes Militares" 108).

${ }^{30}$ Salazar estabelece uma distinção entre violência e força. A primeira é arbitrária, enquanto que a segunda procura restabelecer a legalidade numa situação de desordem. Salazar condena a violência mas afirma que a força é necessária ("O Momento Político" 70-1). Em Chaimite, a actuação do exército é considerada uma manifestação de força mas não de violência, já que os rebeldes são vistos como ameaças à legítima soberania de Portugal sobre os territórios africanos.
} 


\section{Chaimite}

inabalável dos europeus nas grandes certezas espirituais da religião, do patriotismo e dos valores familiares. Mouzinho de Albuquerque proclama mesmo em várias etapas da narrativa o seu desejo de morrer pela pátria, morte que seria não só heróica mas também certamente recompensada por Deus, já que se encontraria ligada à expansão dos valores cristãos em terra pagã. ${ }^{31}$ Cabe aos africanos abandonar a sua confusão moral e admitir o valor dos ideais espirituais defendidos pelos portugueses, reconhecendo assim simultaneamente a sua própria menoridade, da qual só se poderão libertar submetendo-se aos colonizadores. Verifica-se aqui a extensão da lógica neo-kantiana que o regime moldou e subordinou aos seus propósitos na metrópole: se os portugueses são tanto mais livres, quanto mais se submetem aos princípios do Estado Novo, os colonizados atingem esta liberdade ao abraçarem as mesmas ideias, agora mediadas pela colonização portuguesa.

A representação fílmica da superioridade moral dos colonizadores culmina em Chaimite, local onde ocorre a derrota de Gungunhana, um dos principais comandantes militares dos rebeldes. Os portugueses, encabeçados por Mouzinho de Albuquerque, logram penetrar na fortaleza onde se encontram os revoltosos. O filme evidencia a presença imponente de Mouzinho, na medida em que os africanos, apesar de se encontrarem munidos de armas, não disparam e fogem do português. Quando Gungunhana é finalmente identificado e capturado, após ter sido abandonado pelos seus soldados, Mouzinho, que tem o preso em pé à sua frente, ordena-lhe que se ajoelhe. Gungunhana começa por olhar para o comandante de uma forma provocadora, recusando-se a obedecer. Durante vários segundos a imagem concentra-se nos dois homens, que se olham firmemente nos olhos. A cena termina com Gungunhana a baixar o olhar, e a tomar consciência da sua subalternidade ao vê-a exteriorizada na mirada do europeu. O africano aceita, assim, não só a primazia militar do

\footnotetext{
31 Jorge Seabra salienta o fatalismo da personagem de Mouzinho de Albuquerque que Brum do Canto descreve numa entrevista como "enamorado da morte, guerreiro genial e homem de superior carácter" (citado em Seabra 240).
} 


\section{Patrícia Vieira}

português mas igualmente a sua vitória moral. Quando Gungunhana se submete, os restantes negros dão salvas que Mouzinho interpreta como manifestações de alegria pela prisão do seu líder, sugerindo-se assim que os africanos eram oprimidos pelos seus próprios chefes e desejavam as vantagens trazidas pela colonização.

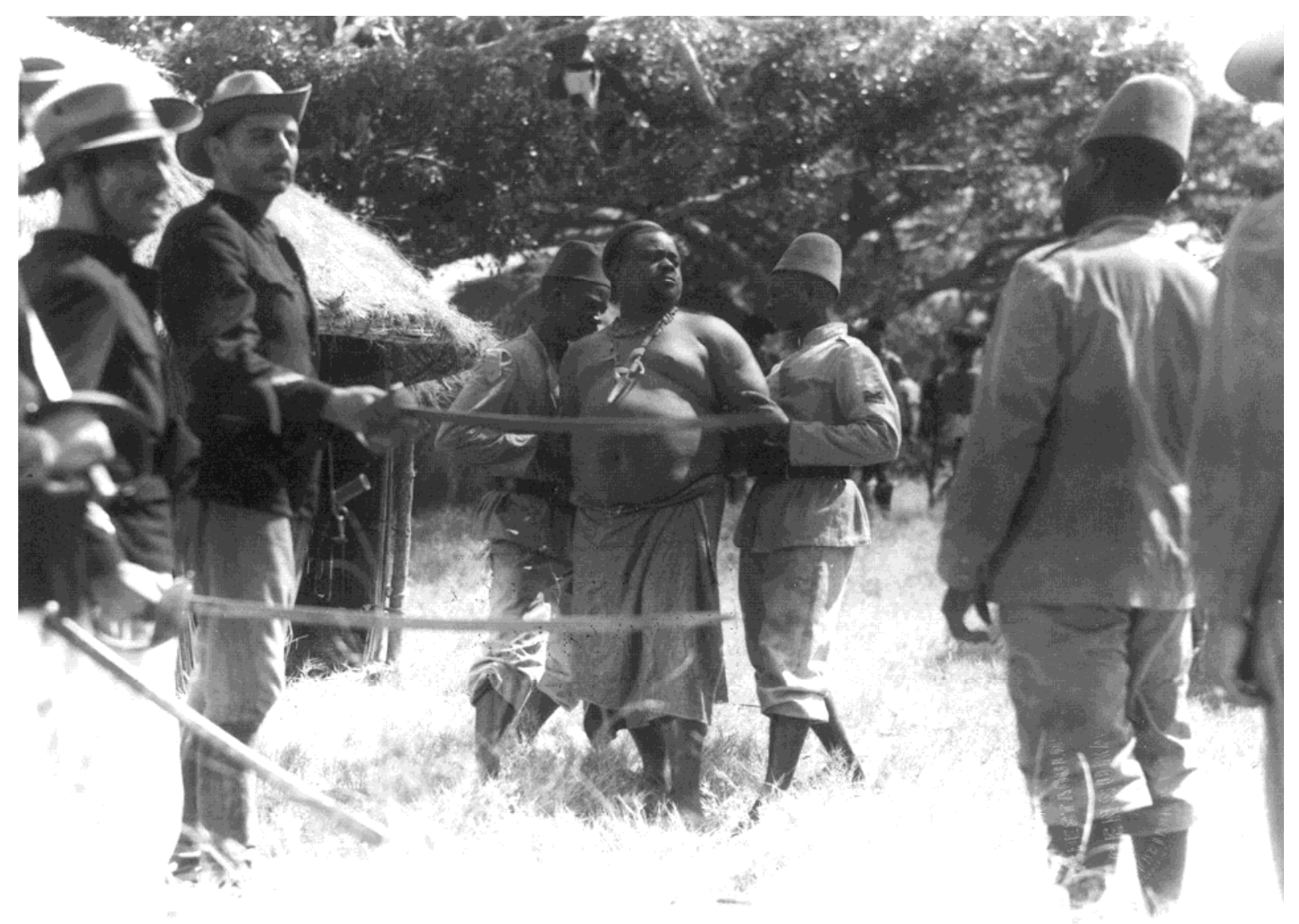

A prisão de Gungunhana em Chaimite

O patriotismo e coragem dos portugueses perpassam as várias classes sociais, sendo que os colonos manifestam frequentemente o desejo de combater e alistam-se entusiasticamente no exército. Esta superioridade moral verifica-se não apenas num contexto bélico mas também durante os intervalos entre combates. Os soldados cantam e tocam melodias evocativas da pátria, que contrastam com os batuques guerreiros dos africanos, e salienta-se a religiosidade dos portugueses que celebram o Natal e dia da Purificação da Virgem. ${ }^{32}$ As qualidades lusitanas contrastam tanto

\footnotetext{
32 Quando os rebeldes atacam Lourenço Marques na noite de Natal de 1894 os portugueses comentam "nem ao menos hoje," sugerindo que os revoltosos são, além de traidores, ímpios. Por outro lado, a casa de António está decorada com um crucifixo que surge de forma proeminente na maioria dos diálogos entre este e a esposa. Personagem complexa, já que foi um desertor no passado e se redime depois pela coragem que exibe na luta contra os revoltosos, António é um dos representantes do povo
} 


\section{Chaimite}

com a situação dos africanos como com a condição dos estrangeiros. Com efeito, o filme menciona com alguma frequência outros povos europeus. Estes surgem por vezes como uma entidade perante a qual os portugueses têm, de certa forma, de prestar contas e mostrar uma imagem positiva. Assim, quando após uma batalha as tropas regressam desalinhadas a Lourenço Marques, um dos comandantes lembra aos soldados que estes vão ser vistos por estrangeiros, pelo que devem aprumar-se e marchar com confiança. Numa outra ocasião, quando a moral se encontra baixa entre os combatentes, um dos chefes do exército profere um discurso no decorrer do qual pergunta: "O que não zombariam os estrangeiros e folgariam os rebeldes se a nossa coluna parasse ou voltasse para trás?" Esta preocupação com a opinião de estrangeiros reflecte, por um lado, a situação geopolítica de finais do século dezanove, já que, após o Ultimato inglês, os portugueses procuravam cimentar a sua soberania sobre as colónias africanas que ainda possuíam, em áreas frequentemente cobiçadas por outras potências coloniais (Pina, História 128). Por outro lado, a relevância da perspectiva dos estrangeiros poderá ser um reflexo da situação da Europa nos anos cinquenta e da crescente pressão internacional sobre o Estado português para que este caminhasse para um regime democrático e conferisse independência às suas províncias ultramarinas. É de notar que, na citação do filme acima transcrita, os estrangeiros são mencionados junto com os rebeldes, como se ambos se aliassem no propósito de coarctar a acção colonizadora dos lusitanos. ${ }^{33}$

O carácter hostil da presença estrangeira é ainda mencionado numa conversa entre Paiva Couceiro, Mouzinho de Albuquerque, a sua esposa Maria José, e Caldas Xavier na

português no filme. A sua religiosidade e patriotismo permitiram-lhe ultrapassar um erro passado e ser readmitido no reduto da pátria. $\mathrm{O}$ filme sugere que o mesmo não acontecerá com os rebeldes africanos.

$33 \mathrm{O}$ filme insinua em vários momentos que os estrangeiros estavam interessados numa derrota das tropas portuguesas. Contudo, a obra de Brum do Canto evita referências à situação internacional que envolvia Moçambique em finais do século dezanove, concentrando-se antes nas vitórias dos portugueses sobre os revoltosos africanos (Seabra 244). 
qual se comenta que Paiva Couceiro bateu em três jornalistas estrangeiros porque estes tinham, entre outras declarações, afirmado que a batalha de Marracuene fora um desastre e que os portugueses eram cobardes. Este diálogo constitui uma versão modificada do roteiro original, no qual estava planeada a filmagem das cenas de espancamento dos jornalistas. A sequência foi cortada pela censura com a alegação que poderia "levantar atritos internacionais" (Seabra 246), afirmação que deverá mais uma vez ser entendida no contexto da conjuntura internacional do pós-guerra. A mendacidade dos estrangeiros no filme constitui uma forma de acentuar que Portugal é o verdadeiro herdeiro dos ideais europeus do espírito, valores estes que se perderam com a decadência moral do resto da Europa identificada por Salazar em vários dos seus discursos. ${ }^{34}$

Como já assinalei, Chaimite apresenta os portugueses como um povo vocacionado para a paz, sendo que a guerra irrompe apenas como resposta à revolta dos africanos. Com efeito, o filme sublinha que o confronto militar surge como defesa da terra, sendo que o objectivo é permitir que os colonos regressem às suas actividades de comércio ou cultivo. Subjaz assim à narrativa a noção da união entre o Portugal metropolitano e os seus territórios ultramarinos, conceito ao qual Salazar alude frequentemente: "Tal qual como o Minho ou a Beira é, sob a autoridade única do Estado, Angola ou Moçambique ou a Índia. Somos uma unidade jurídica e política, e desejamos caminhar para uma unidade económica" (“A Nação na Política Colonial” 234-5). Portugal é um país cujo território se encontra localizado em diversos continentes mas esta variedade não põe em causa a soberania da nação sobre as suas regiões: "Entre nós,

\footnotetext{
${ }^{34}$ Se a Europa ocidental e os Estados Unidos pressionam o Estado Novo a partir de finais dos anos quarenta no sentido de conferir independência aos territórios ultramarinos, Salazar considera que o bloco soviético constitui igualmente uma ameaça para as colónias portuguesas: "O comunismo soviético, multiforme na sua identidade doutrinal, perfilha o nacionalismo na Ásia e o internacionalismo na Europa. [...] Se ali triunfa [no Extremo Oriente], não tardará muito que deite o fogo à África" ("O meu Depoimento" 355). O comunismo é assim um perigo tanto para a integridade de Portugal continental como para as colónias.
} 


\section{Chaimite}

constituímos a variedade da unidade [...] perante os outros países somos simplesmente a unidade, um só e o mesmo em toda a parte" (“A Nação na Política Colonial” 235). Esta unidade é explicada através de uma metáfora familiar:

[mantemo-nos] unidos, por laços de parentesco, de vida económica e política, de cultura e de fé, à roda da lareira, na velha casa paterna, quando o mundo parece se esboroa e decerto se divide em irredutibilidades e ódios. No meio das convulsões presentes nós apresentamo-nos como uma irmandade de povos, cimentada por séculos de vida pacífica e compreensão cristã, comunidade de povos que, sejam quais forem as suas diferenciações, se auxiliam, se cultivam e se elevam, orgulhosos do mesmo nome e qualidade de portugueses. ("A Nação Portuguesa Irmandade" 282)

Salazar estende a sua concepção de família à relação entre a metrópole e o Ultramar e aplica sua visão patriarcal das relações entre parentes às colónias. Apesar de proclamar que todos os povos unidos sob a soberania portuguesa são como irmãos, estes devem reunir-se "na velha casa paterna" e obedecer às leis portuguesas. Neste regime paternalista a rebeldia dos filhos é inaceitável e quaisquer esforços de independência serão brutalmente punidos, como se verifica em Chaimite.

O filme de Brum do Canto expressa a ligação entre Portugal e as suas províncias ultramarinas de uma perspectiva subjectivada, ao enfatizar o apego dos colonos à terra africana. Num diálogo em que Daniel (Artur Semedo) comunica a dois amigos que se vai alistar no exército afirmase: "Esta terra é uma coisa nossa, uma coisa que nos toca a todos [...] É a defesa da nossa terra invadida por esses selvagens. [...] É a defesa das nossas famílias." Inverte-se aqui a realidade histórica do processo de colonização, sendo que os africanos são qualificados como "selvagens" invasores de uma região que, por direito, pertence aos europeus. Como declara Salazar no seu discurso "O Império Colonial na Economia" os portugueses que partem para as colónias reconhecem que "ali é Portugal" (162). Quando Daniel, dono de um bar em Lourenço Marques, conhece Maria, uma jovem recém-chegada de uma aldeia portuguesa a Moçambique para se juntar à sua tia, ambos professam o 


\section{Patrícia Vieira}

seu desejo de ter "uma casa no mato, ao pé de um ribeiro, com terrenos à volta para cultivar," expressão que se torna um leitmotiv no filme. ${ }^{35}$ Daniel e Maria acabam por se casar e deixar a cidade para realizarem o seu ideal campestre em África. Instalam-se numa área desabitada, constroem uma casa, cultivam a terra e, após alguns meses, o casal mostra-se orgulhoso por ter fundado uma nova aldeia. As plantações crescem, Maria tem um filho, chegam novos colonos ao local e vai construir-se uma igreja. ${ }^{36}$ Mais uma vez nas palavras de Salazar: "Não é a terra que se explora: é Portugal que revive" ("Portugal perante a Crise" 43).

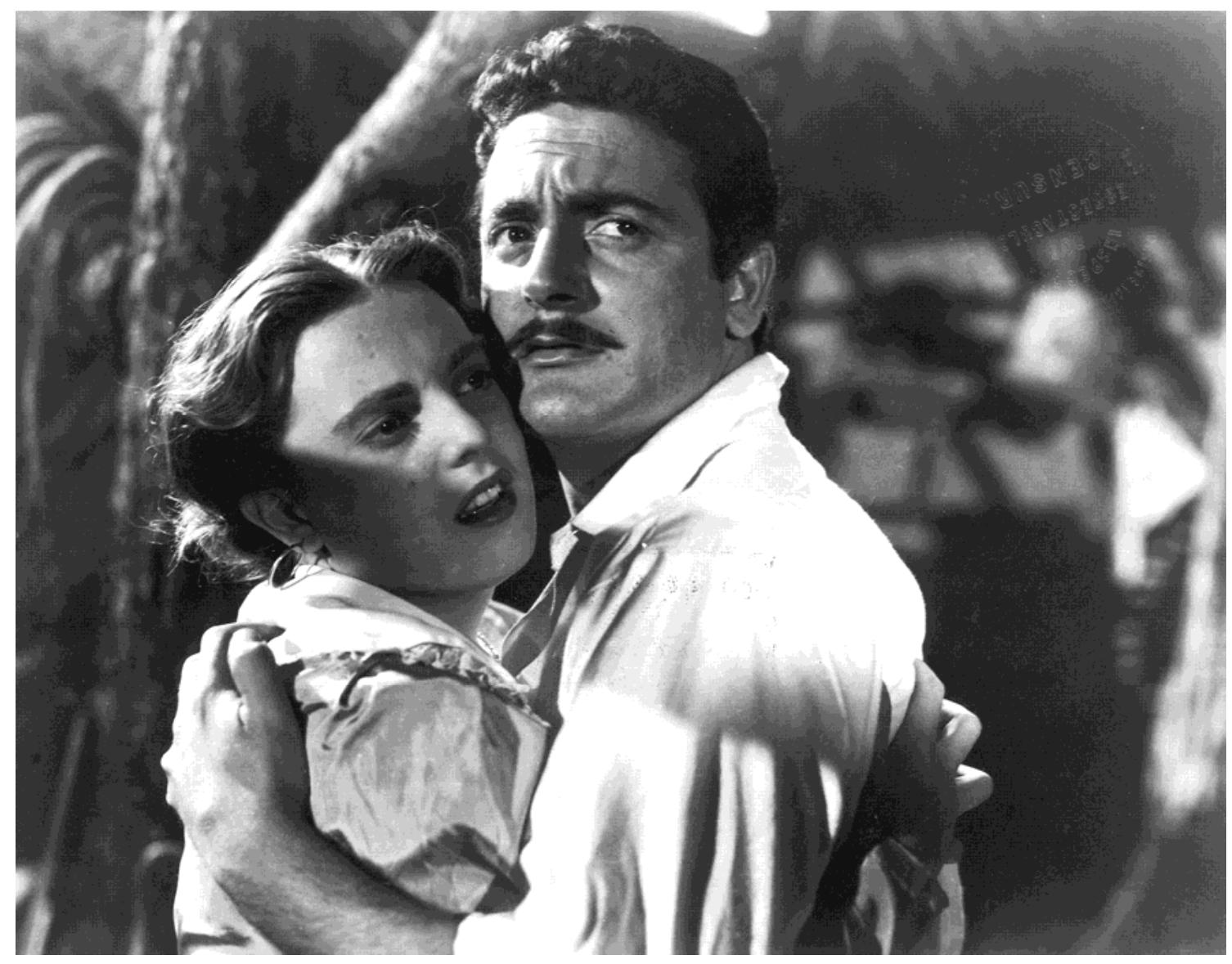

Maria e Daniel em Chaimite

A dedicação à terra representada em Chaimite resulta de uma transposição do ideal de ruralidade propagado pelo salazarismo na metrópole aos domínios de além-mar.

A glorificação da vida campestre constitui um traço fundamental do Estado Novo, que o regime procura difundir atra-

${ }^{35}$ A primeira imagem de Maria apresenta-a a cultivar um terreno com a tia. As duas refugiam-se em Lourenço Marques quando eclode a revolta dos africanos e alojam-se no café de Daniel, que tem alguns quartos livres. ${ }^{36} \mathrm{O}$ idílio de Daniel e Maria na sua plantação termina quando os africanos incendeiam os campos. Esta acção, condenada no filme, constitui um sinal de que o ideal agrário português não pode ser facilmente implantado no território africano, onde preexistem outras formas de povoamento que não são tomadas em consideração pelos colonos. 


\section{Chaimite}

vés de várias iniciativas do SPN/SNI, tais como a competição da "Aldeia mais Portuguesa de Portugal" ou a criação do Museu de Arte Popular em 1948. Esta idealização da vida rústica é herdeira de uma tradição bucólica que remonta à Antiguidade Clássica, com as éclogas de Virgílio, por exemplo, e que é retomada no Renascimento português, período durante o qual poetas como Sá de Miranda fizeram uma apologia do bucolismo como espaço de resistência a uma decadência moral generalizada, pela qual os rápidos lucros resultantes da expansão ultramarina eram em parte responsáveis. Miranda expressa ainda a sua admiração pelo ideal horaciano da "aurea mediocritas," associado ao mito da Idade de Ouro, que representa a actividade agrária em traços idílicos. Estes temas são frequentemente retomados nas letras portuguesas, notavelmente por Eça de Queirós em $A$ Cidade e as Serras, obra na qual o protagonista abandona uma vida faustosa em Paris e se radica na pequena aldeia de Tormes, onde se torna proprietário rural. $\mathrm{O}$ estadonovismo apropria-se desta tradição ao salientar as virtudes dos camponeses portugueses - trabalhadores e honrados, austeros mas generosos - os quais representam a perfeita união entre o espírito e a matéria. ${ }^{37} \mathrm{~A}$ obra de Brum do Canto documenta assim a transmutação do ethos camponês português em África. Curiosamente, foram as descobertas ultramarinas, que Sá de Miranda opunha ao ideal bucólico, que permitiram a implantação deste ideal em terras africanas.

Se Chaimite enfatiza o desenvolvimento agrário das regiões ultramarinas, o que se coaduna com a restante filmografia de Brum do Canto, ${ }^{38}$ não deixa de assinalar o progresso da actividade comercial sob o domínio dos portugueses. O café Chai-Chai, que pertence a Daniel, é o epítome desta evolução já que, sob o impulso da Tia Rosa, que aqui se refugia com Maria, se eleva primeiro a restau-

\footnotetext{
${ }^{37} \mathrm{O}$ ruralismo é muito vulgar no pensamento fascista. No caso português, encontramos esta doutrina em ideólogos do regime como António Correia de Oliveira.

${ }^{38}$ Em filmes como A Canção da Terra (1938) ou A Cruz de Ferro (1968) Brum do Canto salienta a ligação entre o povo português e a terra por ele cultivada. Este ruralismo é uma constante na sua filmografia (Seabra 237).
} 


\section{Patrícia Vieira}

rante e depois a hotel. O próprio Brum do Canto afirma que pretendeu com o filme,

despertar, no espírito do espectador [...] o amor pela terra de África, tão portuguesa como a de cá-através do espírito construtivo que, na cidade, eleva o Chai-Chai primeiro de café a restaurante e depois a hotel-e que, no campo, impulsiona Daniel, recém-casado, a lançar os alicerces duma cidade futura, transformando o inaproveitado mato virgem em valor real de prosperidade (citado em Seabra 242). ${ }^{39}$

Ressalta nesta declaração a ideia de que tanto a agricultura como o comércio não seriam desenvolvidos pelos africanos, o que se transforma em mais uma justificação para a colonização portuguesa.

No filme, o motor do desenvolvimento económico das províncias ultramarinas é o povo, ou seja, os colonos provenientes das camadas menos favorecidas da população em Portugal, tais como António, Maria, Daniel ou João Macário, sendo que não é atribuído um sobrenome aos dois últimos precisamente porque eles têm como função representar toda uma classe (ver Brum do Canto, citado em Seabra, 242). Contudo, mais do que João Macário, o pretendente que Maria rejeita, é Daniel, com quem esta se casa, que melhor simboliza o ideal colonizador, na medida em que nele se conciliam o impulso guerreiro e agrário dos portugueses - os dois pólos entre os quais oscila a acção do filme. O confronto entre estas duas realidades surge mesmo antes do início da narrativa, já que a música que acompanha os créditos abre em tom épico para depois se transformar numa melodia mais leve e alegre. Da mesma forma, o desenrolar das várias batalhas travadas contra os rebeldes africanos é acompanhado pelo progresso da história de amor entre os dois jovens. Quando estes se casam e estão prestes a partir para o local onde irão erguer a sua casa e estabelecer uma plantação,

\footnotetext{
39 Esta iniciativa privada coaduna-se com a política colonial do regime. Salazar condena o que ele define como o "fetichismo do Estado" e diz que a economia nacional não pode ser reduzida à economia estatal. O chefe do governo enfatiza assim a necessidade da acção privada dos portugueses nas colónias, sem a exigência de fundos públicos ("O Império Colonial na Economia" 165-6).
} 


\section{Chaimite}

Mouzinho de Albuquerque faz um discurso no qual louva Daniel:

O Daniel pode servir de exemplo. Sim, porque o problema não é só defender a terra portuguesa dos vátuas invasores, é também aproveitá-la, cultivá-la, transformá-la em rendimento e prosperidade. O Daniel trabalhou na defesa da terra, agora vai trabalhar na sua glorificação, completando assim a obra iniciada. És um exemplo, rapaz, não há dúvida.

Se, durante o período da expansão ultramarina portuguesa, o ideal bélico é frequentemente contraposto tanto à agricultura como ao comércio, estas vertentes reconciliam-se em Chaimite na pessoa de Daniel, soldado e colono, dono de um café em Lourenço Marques e, mais tarde, de uma plantação no interior de Moçambique. ${ }^{40}$ Os valores do espírito definidos pelo salazarismo encarnam assim tanto no impulso guerreiro de defesa de uma região que se considera portuguesa como no cultivo da terra, actividade cujos lucros reverterão em parte para o estado. A conquista precede e cria as condições para agricultura que, por sua vez, cimenta o domínio colonial conseguido pela força das armas:

O que está feito é mais - é a fusão da raça e da terra, o alargamento, até aos confins do sertão, das estreitas fronteiras da península, a mesma Pátria reproduzida, alma e sangue, ao modo de Mãe em seus filhos. [...] A charrua penetra o solo mais que o ferro da espada; o suor fertiliza a terra, mais que o sangue das veias; o espírito afeiçoa e transforma os homens e a natureza mais profundamente que a força material dos dominadores. (Salazar, "Portugal perante a Crise" 42)

De acordo com Salazar, o objectivo final da colonização, espelhado em Chaimite, é a transformação das províncias

\footnotetext{
40 No século quinze, os portugueses vacilaram entre um modelo de expansão ultramarina baseado na conquista de territórios pelas armas, à semelhança do que se passou em Ceuta, e uma ênfase no comércio, que requereria um menor esforço bélico. Por outro lado, esta expansão, tanto na sua faceta guerreira como comercial, era considerada por alguns como um entrave ao desenvolvimento agrícola do país. Como afirma Sá de Miranda na famosa carta a António Pereira: "Não me temo de Castela,/ Donde inda guerra não soa,/ Mas temo-me de Lisboa/ Que, ao cheiro desta canela,/ O Reino nos despovoa" (482).
} 


\section{Patrícia Vieira}

ultramarinas numa réplica da metrópole, o que se concretizaria não só pela força mas através de uma transposição da sociedade agrária portuguesa para África.

Para atingir o objectivo da recriação das estruturas materiais, económicas e, principalmente, dos valores estadonovistas do espírito nas províncias ultramarinas, é necessária a manutenção da ordem social existente em Portugal. Em Chaimite, há uma clara divisão entre o povo e a classe dirigente, representada pelos comandantes do exército e as suas famílias. Esta separação expressa-se no filme através de cenas consecutivas, onde os líderes e o povo desempenham as mesmas acções em cenários separados. Assim, à refeição simples de Daniel, Maria, Tia Rosa e João, segue-se o repasto elegante de Paiva Couceiro, Caldas Xavier, Mouzinho de Albuquerque e Maria José. Daniel despede-se de Maria imediatamente antes de Mouzinho se despedir da esposa e a leitura de uma carta enviada por Daniel quando este está no exército é precedida por uma cena em que Maria José lê uma carta de Mouzinho. A ênfase no paralelismo entre dirigentes e o povo será possivelmente uma forma de acentuar a igualdade entre os portugueses, na medida em que todos se dedicam às mesmas actividades. ${ }^{41}$ No entanto, a segregação de classes neste filme, como em outros do mesmo período, ${ }^{42}$ revela que, no Estado Novo, a hierarquia social é essencial para a manutenção de uma sociedade próspera. Os membros da classe popular, responsáveis pelo desenvolvimento das colónias, prosperam na medida em que

\footnotetext{
${ }^{41}$ Numa entrevista com Jorge Seabra, Brum do Canto afirma que quis em Chaimite mostrar o "portuguesismo," ou seja, "aquilo que faz com que sejamos portugueses e não sejamos franceses" (citado em Seabra 242). No filme, este "portuguesismo" é comum a todas as classes sociais e constitui um traço de união nacional.

${ }^{42}$ Um exemplo seria O Costa do Castelo (1943), realizado por Arthur Duarte. Apesar da reconciliação de classes no final da narrativa, o tema da segregação perpassa toda a obra. Quando Rita (Maria Olguim) e Januário (João Silva), representantes do povo, se mudam para a casa dos aristocratas Mafalda (Maria Matos) e Simão (Manuel Santos Carvalho) para acompanhar Luisinha (Milu), estes ficam instalados nos aposentos dos empregados. A acção dos donos da casa acontece no andar superior, paralelamente ao desenvolvimento da história dos mais pobres, no andar inferior.
} 


\section{Chaimite}

obedecem aos seus superiores e se mostram subservientes e prontos a aceitar as ordens dos comandantes, dos quais emanam sabedoria, coragem e justiça. Assim, António e Daniel admiram o patriotismo de Paiva Couceiro e Mouzinho de Albuquerque e declaram-se prontos a morrer ao serviço dos comandantes. Mouzinho e a esposa servem de padrinhos de casamento de Daniel e Maria, sendo que a união entre os primeiros deverá constituir um exemplo para os segundos. Finalmente, Maria aprende com a esposa de Mouzinho a melhor servir o seu marido, já que Maria José, que acompanha Mouzinho na guerra como enfermeira, encoraja Maria a fazer o mesmo. ${ }^{43}$

Chaimite sugere que as verdades espirituais se disseminam verticalmente, permeando a sociedade a partir do topo. Evidentes para alguns, estas noções têm que ser reveladas a outros, confusos na sua ignorância, por uma elite iluminada. Como afirma Salazar, "os grandes problemas nacionais têm de ser resolvidos, não pelo povo, mas pelas elites, enquadrando as massas" (Ferro, Entrevistas 183). Os valores espirituais que emanam da religião e encarnam no Estado Novo são transmitidos ao povo através de um escol de dirigentes. $\mathrm{O}$ regime pressupõe assim a existência de uma cadeia hierárquica de matriz paternalista que se inicia com Deus, passa pelos governantes políticos, militares e religiosos, incluindo o próprio Salazar, difunde-se depois pelas classes populares e chega finalmente às populações nativas

\footnotetext{
${ }^{43}$ Chaimite apresenta vários traços de proto-feminismo. A esposa de Mouzinho de Albuquerque declara ser injusto que as mulheres não possam combater junto com os homens. Mais tarde, resolve seguir o marido para o campo de batalha no papel de enfermeira e convence Maria a fazer o mesmo. A tia Rosa declara que, se pudesse, combateria os africanos com o rolo da massa, lembrando assim outras figuras populares femininas envolvidas em actos heróicos, tais como a Padeira de Aljubarrota ou Maria da Fonte. Contudo, estas iniciativas das mulheres portuguesas nunca põem em causa a sua principal função de acompanhantes das personagens masculinas, que são os verdadeiros protagonistas da luta contra os rebeldes. A coragem das mulheres portuguesas torna ainda mais evidente a humilhação das africanas. A mãe de Gungunhana suplica a Mouzinho de Albuquerque que este a mate em vez do filho, pedido ao qual o militar responde declarando que o destino de Gungunhana está nas mãos do rei de Portugal.
} 


\section{Patrícia Vieira}

das províncias africanas através dos colonos. Esta ordem social é a concretização da solidez moral de um povo e, simultaneamente, condição para o seu progresso material. Os laços estabelecidos entre os diferentes escalões da hierarquia representados no filme tornam manifestos os vínculos que unem, da metrópole às colónias, todos os membros da nação portuguesa, elos estes forjados pelas "grandes certezas" do espírito.

Chaimite enquadra-se no desiderato estadonovista de criar uma "Política do Espírito" que propague os valores morais nos quais se fundamenta o regime. Nas palavras do produtor, Luiz Pinto Coelho, no folheto em que apresentou o filme:

Considerou-se em primeiro lugar a alta função que o Cinema pode e deve desempenhar na criação, conservação e desenvolvimento dos valores espirituais e morais que fazem grandes os homens e os povos, mesmo os humildes e os povos pequenos (ênfase acrescentada, citado em Seabra 242).

Esta difusão das verdades que acompanham o desenvolvimento espiritual do Estado Novo nas colónias pressupõe a reprodução da sociedade portuguesa nas províncias ultramarinas, particularmente na sua vertente agrária. Para esta transposição da metrópole para África conta-se com a capacidade de adaptação dos portugueses, simbolizada por Maria, que aprende a expressão africana "maningue"-_muito" em português. Ao fazer desta a última palavra do filme, Brum do Canto terá talvez pretendido sublinhar que, em troca de algumas concessões e do reconhecimento de certos elementos mais exóticos da cultura africana, o antagonismo dos colonizados se desvanecerá. ${ }^{44}$ Espera-se que os africanos reconheçam a superioridade

\footnotetext{
${ }^{44}$ Salazar afirma que o sucesso da colonização levada a cabo pelos portugueses se deve à sua capacidade de adaptação, que inclui uma faceta linguística: "Le Portugais n'hésite pás à vulgariser les mots de sa langue maternelle et à l'enrichir des nouvelles expressions qu'il juge indispensables" (Garnier 154). Jorge Seabra salienta o rigor linguístico do filme de Brum do Canto. A comunicação entre brancos e africanos é feita primeiro em landim e depois em ngoni, na medida em que o inimigo muda dos landins para os vátuas.
} 


\section{Chaimite}

moral dos portugueses e as vantagens em se submeterem ao seu domínio, e que a revolta dos vátuas fique para a história como mais uma etapa gloriosa da colonização portuguesa, em que os ideais europeus de espiritualidade triunfaram sobre a desordem.

Mas se a soberania portuguesa sobre as colónias constitui uma forma de levar aos africanos as verdades do espírito, a rebelião que o filme descreve mostra que os colonizados não se revêem necessariamente na sua condição de menoridade. Como afirma Hegel, o movimento do espírito desenrola-se na história da humanidade numa progressão dialéctica. $\mathrm{O}$ filósofo justifica o domínio europeu sobre África na medida em que considera que o continente africano não possui história, sendo que o espírito se encontra, nestas circunstâncias, completamente separado de si mesmo. A colonização europeia seria assim uma forma de introdução violenta da dialéctica histórica no continente, devir através do qual o espírito se torna auto-consciente. As implicações da teoria hegeliana permitem antecipar que, em algum momento, os colonizados se tornarão consci-entes da precariedade da posição dos colonizadores. Os africanos aperceber-se-ão que os senhores estão dependentes dos escravos e que a sua posição de superioridade só se mantém enquanto existirem subalternos. Quando os colonizados assim se apropriarem do espírito, o exército português não poderá já conter a sua revolta. Este foi o momento que, ensimesmado numa crença na evidência universal dos seus valores, o Estado Novo não previu.

Nas primeiras cenas de Chaimite, quando deflagra a rebelião africana, António, um colono português, corre ao quartel-general do exército em Lourenço Marques para avisar as autoridades de que se encontrava em curso uma revolta. Os militares, sentados numa sala com as janelas fechadas, ficam surpreendidos com a notícia e parecem duvidar de que tal acontecimento fosse possível. Contudo, basta a António abrir as janelas do edifício para se ouvirem lá fora os gritos da população e dos revoltosos. Ao querer proteger as "grandes certezas" do espírito de convulsões sociais, o Estado Novo fechou-se também por detrás de janelas, isolando-se de verdades alternativas tanto na metró- 


\section{Patrícia Vieira}

pole como nas províncias ultramarinas. Esta desconexão reflecte-se na obra de Brum do Canto que apresenta a revolta dos vátuas filtrada pela ideologia do regime, filmando como que por detrás de uma janela fechada, sem se aperceber do que se passa lá fora.

Bibliografia:

A Obra Colonial do Estado Novo. Lisboa: SPN e Agência Geral das Colónias, 1942.

Almeida, António. Política Colonial Portuguesa no Passado e no Presente. Lisboa: Agência Geral das Colónias, 1942.

António, Lauro. Cinema e Censura em Portugal, 19261974. Lisboa: Arcádia, 1978.

Brum do Canto, Jorge, dir. Chaimite. Lisboa: Cinal, Cinematografia Nacional, 1953

Costa, Alves. Breve História do Cinema Português (18961962). Lisboa: Instituto da Cultura Portuguesa e Secretaria de Estado da Investigação Científica, 1978.

Ferro, António. "Grandeza e Miséria do Cinema Português." Teatro e Cinema (1936-1949). Lisboa: Edições SNI, 1950. 43-57.

---. "O Estado e o Cinema." Teatro e Cinema (1936-1949). Lisboa: Edições SNI, 1950. 61-78.

---. A Política do Espírito e os Prémios Literários do S.P.N. Lisboa: Edições SPN, 1935.

---. Entrevistas a Salazar. Lisboa: Parceria A. M. Pereira, 2003.

---. Política do Espírito. Apontamentos para uma Exposição. Lisboa: Edições SNI, 1948.

Garnier, Christine. Vacances avec Salazar. Paris: Grasset, 1952.

Guedes, Fernando. António Ferro e a sua Política do Espírito. Lisboa: Academia Portuguesa da História, 1997.

Hegel, G. W. Reason in History. A General Introduction to the Philsophy of History. Trans. Robert S. Hartman. Upper Saddle River (NJ): Prentice Hall, 1997. 
Husserl, Edmund. The Crisis of European Sciences and Transcendental Phenomenology. Evanston: Northwestern University Press, 1970.

"Leitura Obrigatória." Amordeperdicao.pt. 2003. Associação para a Promoção do Cinema Português. 17 de Junho de 2008.

$<$ http://www.amordeperdicao.pt/especiais_solo.asp?artigoid $=206>$.

Monteiro, Amindo. "Directrizes duma Política

Ultramarina." Conferência do Império Colonial. Lisboa, Agência Geral das Colónias. s.d. 11-33.

Ó, Jorge Ramos do. Os Anos de Ferro. O Dispositivo Cultural Durante A "Política do Espírito” 1933-1949.

Ideologia, Instituições, Agentes e Práticas. Lisboa: Editorial Estampa, 1999.

Paulo, Heloísa. Estado Novo e Propaganda em Portugal e no Brasil. O SPN/SNI e o DIP. Coimbra: Livraria Minerva, 1994.

Pina, Luís de. História do Cinema Português. Lisboa: Publicações Europa-América, 1986.

Sá de Miranda, Francisco de. Poesia de Sá de Miranda. Org. Alexandre M. Garcia. Lisboa: Editorial Comunicação, 1984.

Salazar, António de Oliveira. "Para Servir de Prefácio." Discursos (1928-1934). Coimbra: Coimbra Editora, 1935. vii-xxxii.

---. "Elogio das Virtudes Militares." Discursos (19281934). Coimbra: Coimbra Editora, 1935. 99-112.

---. “A Nação na Política Colonial." Discursos (19281934). Coimbra: Coimbra Editora, 1935. 229-37.

---. "Propaganda Nacional." Discursos (1928-1934).

Coimbra: Coimbra Editora, 1935. 257-64.

---. “A Escola, a Vida e a Nação.” Discursos (1928-1934). Coimbra: Coimbra Editora, 1935. 301-10.

---. "O Momento Político. Grandes e Pequenas Questões da Política Portuguesa." Discursos e Notas Políticas (19351937). Vol. II. Coimbra: Coimbra Editora, 1937. 65-87. 


\section{Patrícia Vieira}

---. "O Império Colonial na Economia da Nação."

Discursos e Notas Políticas (1935-1937). Vol. II. Coimbra: Coimbra Editora, 1937. 153-71.

---. "Portugal perante a Crise da Europa." A Política Imperial e a Crise Europeia. António de Oliveira Salazar e Óscar Carmona Lisboa, Edições SPN, 1939. 39-55.

---. "Aos Portugueses da América do Norte." Discursos e Notas Políticas (1938-1943). Vol. III. Coimbra: Coimbra Editora, 1943. 167-9.

---. "Fins e Necessidades da Propaganda Política."

Discursos e Notas Políticas (1938-1943). Vol. III. Coimbra: Coimbra Editora, 1943. 193-211.

---. "Problemas Político-Religiosos da Nação Portuguesa e do seu Império.” Discursos e Notas Políticas (1938-1943). Vol. III. Coimbra: Coimbra Editora, 1943. 231-43.

---. "A Nação Portuguesa Irmandade de Povos." Discursos e Notas Políticas (1943-1950). Vol. IV. Coimbra: Coimbra Editora, 1951. 281-4.

---. “O Meu Depoimento.” Discursos e Notas Políticas (1943-1950). Vol. IV. Coimbra: Coimbra Editora, 1951. 349-81.

---. "Questões de Política Interna." Discursos e Notas Políticas (1943-1950). Vol. IV. Coimbra: Coimbra Editora, 1951. 425-55.

Seabra, Jorge. "Imagens do Império. O Caso Chaimite de Jorge Brum do Canto." O Cinema sob o Olhar de Salazar. Ed. Luís Reis Torgal. Lisboa: Círculo de Leitores, 2000. 235-73.

Sevillano Calero, Francisco. Propaganda y Medios de Comunicación en el Franquismo (1936-1951). Alicante: Publicaciones de la Universidade de Alicante, 1998.

Stam, Robert and Louise Spence. "Colonialism, Racism, and Representation: An Introduction." Film Theory and Criticism. Introductory Readings. Ed. Leo Braudy and Marshall Cohen. New York and Oxford: Oxford University Press, 2004. 877-91.

Torgal, Luís Reis. "Propaganda, Ideologia e Cinema no Estado Novo. A 'Conversão dos Descrentes'.” O Cinema 


\section{Chaimite}

sob o Olhar de Salazar. Ed. Luís Reis Torgal. Lisboa:

Círculo de Leitores, 2000. 64-91.

Valéry, Paul. "The Crisis of the Mind." The Outlook for Intelligence. Ed. Jackson Mathews. Trans. Denise Folliot and Jackson Mathews. New York and Evanston: Harper and Row, 1962. 23-36. 